\title{
Online Focus Group Discussion (OFGD) Model Design in Learning
}

\author{
Tien Yulianti ${ }^{1}$, Ari Sulistyawati ${ }^{2}$ \\ \{tien_yulianti@teknokrat.ac.id ${ }^{1}$, ari_sulistiyawati@teknokrat.ac.id² $\}$ \\ Universitas Teknokrat Indonesia, Bandar Lampung Indonesia ${ }^{1,2}$
}

\begin{abstract}
This study aims to (1) develop learning innovations in the network through the Online Focus Group Discussion (OFGD) model and (2) implement OFGD as a learning media for improving students' public speaking skills of Personality Development. The results of the implementation of the OFGD model in learning are to develop students in using ICT tools as communication media in the network to have competitiveness in the era of the industrial revolution 4.0. This study phase refers to the six steps of developing the ASSURE model. The results of the study obtained FGD method online with the term OFGD consisting of 5 stages. The implementation of OFGD learning models shows the students' public speaking skills, the ability to manage discussions, as well as the ability to use information technology as a communication tool
\end{abstract}

Keywords: Learning Design, OFGD, Public Speaking Skills

\section{Introduction}

Education 4.0 is an education era that is influenced by the industrial revolution 4.0. This education pattern utilizes digital technology in the learning process and is known as the cyber system. This system is able to make the learning process take place continuously without time and space limits. This can be achieved by optimizing the use of technology as a tool of education is expected to produce Human Resources as the output with appropriate quality graduate demands for jobs and digital technology. Education actors must also be alert to adapt to various existing developments.

School is an educational institution that implements the learning process appropriately to help foster the competence and competence of students. The competence of students in the learning process must develop optimally and they can live, run, and count in 21 st century society[1]

As one of the universities that implements an Online Learning System, Universitas Teknokrat Indonesia committes to equipping the students to be competitive in the era of industrial revolution 4.0. The role of educators in the preparation of a more innovative learning system is carried out through the development of learning models to improve students' abilities in the use of ICT. Learning designs that integrate ICT by integrating physical, digital and human objects in the Personality Development course are aimed at producing competitive and skilled of univercities graduates, especially in the technological literacy aspect. This integration can be applied through the online Focus Group Discussion (OFGD) method.

OFGD will optimze the competence of students in ICT mastery. It answer the challange of 21 st Century Skills that the students must have the integration of Knowledge, Skills and Attitudes as well as ICT mastery developed through: (I) Critical Thinking Skills and Problem 
Solving Skills, (2) Communication Skills, (3) Creative Skills and Innovation Skills and (4) Collaboration Skills[2]. Minister of Education and Culture (Mendikbud) Muhadjir Effendy pointed out that every student must have five competencies; (1) Ability to think critically, (2) Have creativity and innovative abilities, (3) Good communication skills and abilities, (4) Ability to work together, and (5) Have high self-confidence. It is an asset that is needed to be able to compete in the era of industrial revolution 4.0.[3]

FGD is a systematic process of collecting data and information on a very specific problem through group discussions[4]. The FGD in this study was intended to gather information about students' understanding of the application of Personality Development courses which are given online in everyday life. Through FGD, students are invited to have the ability to think critically, creatively and innovatively in preparing presentations and group discussions. Furthermore, the implementation of a systematic and focused discussion on a particular focus of problem can build good communication skills and skills that require cooperation and high self-confidence so that the FGD implementation process can run smoothly. The Focus Group Discussion (FGD), which is also referred to as group interviewing, is essentially a qualitative research methodology. It is based on structured, semi-structured, or unstructured interviews[5].

The integration of ICT in this course was then developed with a pattern of discussions and presentations conducted online with the term of Online Focus Group Discussion (OFGD). The development of the OFGD learning model aims to equip students with the ability to design online meetings in the form of presentations and discussions, as well as to collect audience opinion data based on determined themes using the video conference platform as an online discussion medium. Thus, the results of implementing the OFGD model in learning are expected to be able to develop students themselves in using ICT devices as a communication medium in the network so that they have competitiveness in the era of the industrial revolution 4.0.

This study aims to (1) develop online learning innovation through the Online Focus Group Discussion (OFGD) model, as stated by Irwanto[4] that the implementation of FGD requires careful planning, it takes some preparation; forming a team, choosing and arranging a place, preparing logistics, determining the number of participants, and recruiting of participants; (2) implementing OFGD as a learning media for Personality Development as an effort to improve students' public speaking skills, in accordance with the description of the curriculum according to I Ketut Made[6], that it is necessary to formulate and implement self-development programs that aim to provide opportunities for students to develop and express themselves, according to the needs, talents, and interests of each students in accordance with school conditions.

OFGD implementation in Personality Development learning to improve students' Public Speaking ability to focus on the latest issues, in this case the topic of Covid-19 which is given online. Through FGD, students are invited to have critical, creative and innovative thinking skills in preparing presentations and group discussions. Furthermore, implementing a systematic and focused discussion on a particular problem can build good communication skills and skills that require cooperation and high self-confidence so that the FGD implementation process can run smoothly.

\section{The Method of Study}


This research stage refers to the six steps of developing the ASSURE model[7]; (1) Analyze Learners, the process of identifying and analyzing student characteristics tailored to learning outcomes. Regarding the Learning From Home environment (LFH) which was applied during the Covid-19 pandemic, knowledge literacy about Covid-19 as discussion material must be prepared by students, the ability to use ICT and manage online discussions and how to behave in discussions as initial provisions for students to carry out learning implementing OFGD; (2) States Objectives, stating the standards and specific learning objectives for public speaking material in the Personality Development course; the ability of students to apply visual pose, to communicate and to organize discussions online; (3) Select Methods, the process of selecting methods, media and teaching materials to be used in learning. The applied LFH utilizes online learning which is applied through materials delivery using SPADA of Universitas Teknokrat Indonesia, public speaking skills demonstration through OFGD and evaluation to determine the achievement of Personality Development learning targets; (4) Utilize Media and Materials is a teacher planning step to use technology, media and materials to achieve learning goals. This stage is carried out based on the 5P steps, namely Preview (media and materials), Prepare (media and material technology), environmental preparation, student preparation, and providing learning experiences. Computer-based technology is applied in learning. Teaching materials in the form of presentation media and or instructional videos are presented online on SPADA of Universitas Teknokrat Indonesia for Lecturers and Students and showing public speaking skills using the video conference platform as an online discussion medium as OFGD media; (5) Require Learner Participation, where effective learning requires active involvement of students. LFH demands student independence in learning. Learning activities involve an active role of students including providing a discussion "room" using the video conference platform as an online discussion media. Active student involvement and evaluation of the ability to manage discussions online show whether the method used is effective or not; (6) Evaluate and Revise, the assessment of knowledge and skills according to the student's efforts in the learning process and the success of the OFGD implementation in improving public speaking skills analyzed for follow-up reflection. The process of ASSURE Model is decribed on Picture 2.1.

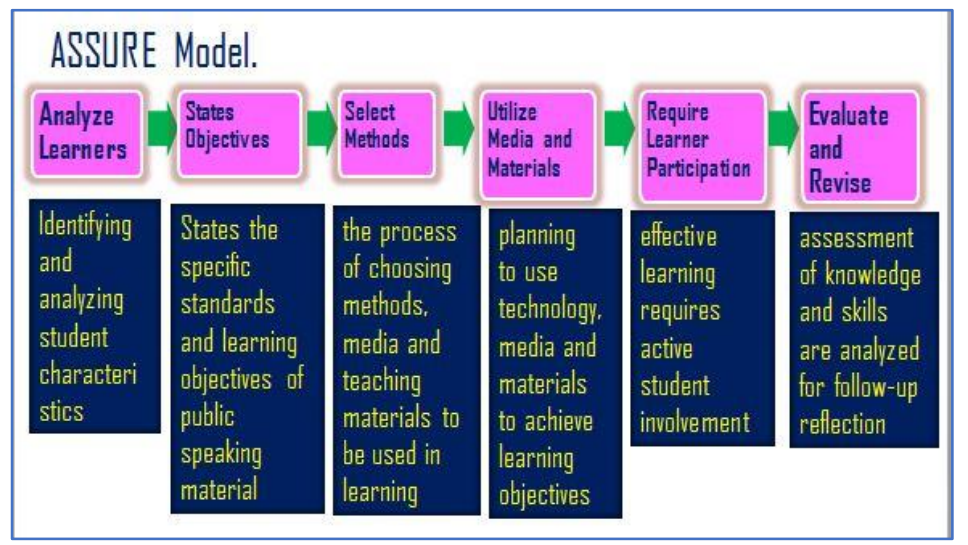

Fig. 1. ASSURE Model Learning Process

Data collection through performance assessment using observation sheet displays the communication skills of students in the discussion forum.

By considering the success of learning outcomes, Yulianti[8] developed a public speaking assessment based on the following matrix. 


\begin{tabular}{|c|c|c|c|c|}
\hline \multirow{2}{*}{ No. } & \multirow{2}{*}{$\begin{array}{l}\text { Assesments } \\
\text { Aspects }\end{array}$} & \multicolumn{3}{|c|}{ Assesment Score } \\
\hline & & 0 & 5 & 10 \\
\hline 1 & Eye Contact & $\begin{array}{l}\text { Avoid audiences' } \\
\text { eye contact }\end{array}$ & $\begin{array}{l}\text { Take eye contact to } \\
\text { some audiences }\end{array}$ & $\begin{array}{l}\text { Take eye contact } \\
\text { to all audiences }\end{array}$ \\
\hline 2 & Facial Expression & $\begin{array}{l}\text { Expressless, } \\
\text { look afraid }\end{array}$ & $\begin{array}{l}\text { No smile, } \\
\text { look doubt } \\
\end{array}$ & $\begin{array}{l}\text { Rilex, } \\
\text { please }\end{array}$ \\
\hline 3 & Voice Intonation & Stammering & $\begin{array}{l}\text { Low, } \\
\text { doubt }\end{array}$ & $\begin{array}{l}\text { Firm, } \\
\text { convincing }\end{array}$ \\
\hline 4 & Body Posture & $\begin{array}{l}\text { Looks } \\
\text { uncomfortable }\end{array}$ & $\begin{array}{l}\text { Sometimes it doesn't } \\
\text { fit to visual pose }\end{array}$ & $\begin{array}{l}\text { Implementing } \\
\text { visual pose }\end{array}$ \\
\hline 5 & Body Movement & Awkward & Doubtful & $\begin{array}{l}\text { Firm, } \\
\text { convincing }\end{array}$ \\
\hline 6 & Hand Movement & No movement & Excessive movement & $\begin{array}{l}\text { Gestures to } \\
\text { emphasize } \\
\text { explanations }\end{array}$ \\
\hline 7 & Speaking Ethics & $\begin{array}{l}\text { Offensive } \\
\text { language }\end{array}$ & \begin{tabular}{|l|} 
Polite, \\
Disorganized \\
Un-systematically
\end{tabular} & $\begin{array}{l}\text { Polite, } \\
\text { well - organized, } \\
\text { systematically }\end{array}$ \\
\hline 8 & Material Mastery & Reading & Memorizing & $\begin{array}{l}\text { Explaining } \\
\text { fluently }\end{array}$ \\
\hline 9 & Grammatical & \begin{tabular}{|l|} 
Too many \\
grammatical \\
errors, so the \\
explanation can \\
bot be understood
\end{tabular} & $\begin{array}{l}\text { Sometimes makes } \\
\text { errors but it does not } \\
\text { influence the } \\
\text { meaning }\end{array}$ & Perfect \\
\hline 10 & Pronunciation & \begin{tabular}{l|} 
Seriously \\
mistakes, so the \\
explanation can \\
bot be understood
\end{tabular} & $\begin{array}{l}\text { Easy to understand, } \\
\text { eventhouh mother } \\
\text { tongue influences }\end{array}$ & $\begin{array}{l}\text { Clear and be } \\
\text { understood }\end{array}$ \\
\hline
\end{tabular}

Fig. 2. Assessment aspects of public speaking

\section{The Result and The Discussion of Study}

The prospect of developing an Online Focus Group Discussion (OFGD) learning model is an innovation in the field of education that is applied using the FGD method which can provide new experiences in the world of education. Through OFGD, students are equipped with the ability to manage discussions and presentations online to achieve learning objectives, especially in the Learning from Home (LFH) condition as a result of learning during the Covid19 pandemic. This is done as an effort to create Indonesian society that is able to compete in the Industrial 4.0 era towards Society 5.0, so the participation of educational institutions is needed to develop learning innovations. In accordance with the goal of national education is to "develop the potential of students to become human beings who believe and fear God Who Almighty, noble, healthy, knowledgeable, competent, creative, independent, and a democratic and responsible citizen[9]. The process of learning process is described on Figure 3.1. 

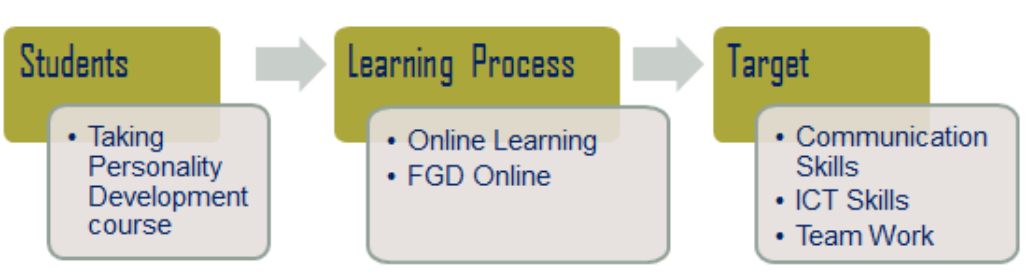

Fig. 3. Learning Process

FGD is a systematic process of collecting data and information on a very specific problem through group discussions[4]. FGD is intended to gather information about students' understanding of the application of Personality Development courses in everyday life. To deal with the learning conditions during the Covid-19 pandemic, the Learning from Home Model (LFH), the FGD learning model was conducted online. Thus, students are invited to have critical, creative and innovative thinking skills in preparing presentations and discussions in a group.

Participant recruitment follows participant identification. Recruitment can be expensive, difficult, and continues to be a source of contentious debate (Krueger \& Casey, 2000)[10]. Basically, FGD can also be used in various domains and objectives, for example (1) decision making, (2) needs assessment, (3) product or program development, (4) knowing customer satisfaction, and so on[11]. In accordance with the characteristics of the FGD which aims to explore and obtain a variety of information on a particular problem or topic which is very likely to be viewed differently with different explanations. So, FGD can also be applied in learning, especially in Personality Development courses in developing student communication skills.

The implementation of OFGD requires careful planning, several preparations are needed as follows: (1) forming a team; (2) selecting and arranging a place; (3) preparing logistics; (4) determine the number of participants; and (5) participant recruitment. The FGD Facilitator Team usually consists of 2-3 people, consisting of: discussion guides (facilitator-moderator), note takers (note takers) and observers[4], the number of FGD participants is smaller 4-7[12], there are 6-8 people[11]. The number of OFGD participants is limited to maximize their opportunity to express their opinion. The phases are describe in Table 1.

Table 1. Learning Phases of the FGD Model

\begin{tabular}{ll}
\hline \multicolumn{1}{c}{ Phase } & \multicolumn{1}{c}{ Description } \\
\hline $\begin{array}{l}\text { Phase1 } \\
\text { Determination of themes, } \\
\text { methods and techniques of } \\
\text { discussion }\end{array}$ & $\begin{array}{l}\text { Determine the theme/ topic, explain the } \\
\text { discussion patterns, techniques and technology } \\
\text { used as a discussion media }\end{array}$ \\
Learning organization & $\begin{array}{l}\text { Create discussion groups and discuss procedures } \\
\text { or steps for collecting and analyzing data; } \\
\text { presentation, assignment of duties as Host along } \\
\text { with the minutes, Moderator and Presenters, and } \\
\text { reporting the results of discussions. }\end{array}$ \\
$\begin{array}{l}\text { Gather information, facts, and data according to a } \\
\text { given theme, followed by analyzing activity }\end{array}$ \\
$\begin{array}{l}\text { Data collecting and analysis } 3 \\
\text { Phase } 4\end{array}$ & $\begin{array}{l}\text { Implementing a focused discussion determined } \\
\text { according to the theme and explore the question - } \\
\text { Implementation }\end{array}$ \\
the question or issue to be discussed together and
\end{tabular}


then draw conclusions - conclusions (answers or quick explanation) the results of discussions

Phase 5

Evaluation and Reflexion
At the end of the learning process, Lecturers and Students evaluate and reflect on the FGD activities and the results of the implementation of their tasks reflect on the FGD activities and the results of the implementation of their assignments.

The results of the study obtained the OFGD learning model to display students' public speaking skills, the ability to manage discussions, as well as the ability to use information technology as a communication tool.

The implementation of OFGD in learning, obtained the results of the measurement of the learning model using 3 scales, the percentage of the measurement value was obtained from the number of samples taken from 355 students. The measurements is taken from Suharsimi[13]. The result of assesment is only take 3 scales; Excellent (A), Good (B), and Fail (E).

The results obtained are the maximum value $=10$ based on the 10 components of the public speaking skills assessment, the average score is 8.1 , and the standard deviation is 1.8 . Based on this data, there were 149 students (42\%) who received a very good assessment, 153 students $(43 \%)$ received a Good assessment, and those who were deemed not meeting the standards in showing their public speaking skills were 53 students $(21 \%)$.

Tabel 2. The result of the percentage measurement of the learning value

\begin{tabular}{cccc}
\hline \multirow{2}{*}{ SCALE } & \multicolumn{3}{c}{ ASSESMENTS } \\
\cline { 2 - 4 } & EXCELLENT & GOOD & BAD \\
\hline Public & $42 \%$ & $43 \%$ & $21 \%$ \\
$\begin{array}{c}\text { Speaking } \\
\text { Skills }\end{array}$ & (149 students) & (153 students) & (53 students) \\
\hline
\end{tabular}

Competent human resources (HR) are one of the main factors determining the success of the transformation of the 4.0 era, therefore improving the quality of human resources (HR) needs to be prioritized. This can be done by preparing students who are able to have competitiveness by developing their competence and potential in optimizing the function of ICT so that the output of Human Resources (HR) with graduate quality is in accordance with the world of work and the demands of digital technology. One form of implementation of $21 \mathrm{st}$ century skills in education can be developed through increasing the communication skills of students through learning public speaking.

\section{Conclusion}

The Focus Group Discussion (FGD) learning model is designed in 5 (five) stages; (1) Determination of discussion themes, methods and techniques; (2) learning organization; (3) data collection and analysis; (4) Implementation; and (5) Evaluation and reflection. The results of the FGD model trial in Personality Development learning in Universitas Teknokrat Indonesia on 355 student samples; $42 \%$ of students showed excellent public speaking skills, $43 \%$ of students demonstrated good skills and $21 \%$ were still unable to demonstrate their skills. 
Acknowledgments. Researchers would like to thank the research funding by the Ministry of Research and Technology / National Research and Innovation Agency in accordance with the Research Contract for Fiscal Year 2020 Number: 839 / SP2H / LT / MONO / LL2 / 2020 dated 24 June 2020 and grateful to LPPM Universitas Teknokrat Indonesia for facilitating it.

\section{References}

[1] Y. F. Selman and A. Jaedun, "Evaluation of The Implementation of 4C Skills in Indonesian Subject at Senior High Schools," vol. 9, no. 2, pp. 244-257, 2020, doi: 10.23887/jpi-undiksha.v9i2.23459.

[2] B. Trilling and C. Fadel, "Bernie Trilling, Charles Fadel-21st Century Skills_Learning for Life in Our Times -Jossey-Bass (2009)," 2009.

[3] F. Adi Saputro, "Mendikbud Ungkap Cara Hadapi Revolusi 4.0 di Pendidikan," https://www.republika.co.id/, 2018. https://www.republika.co.id/berita/pendidikan/eduaction/18/05/02/p8388c430mendikbud-ungkap-cara-hadapi-revolusi-40-di-pendidikan (accessed Mar. 30, 2019).

[4] Irwanto, Focused Group Discussion. Jakarta: Yayasan Pustaka Obor Indonesia, 2017.

[5] B. William, "Evaluating the Efficacy of Focus Group Discussion (FGD) in Qualitative Social Research," Int. J. Bus. Soc. Sci., vol. 3, no. 7, pp. 54-57, 2012, [Online]. Available: http://www.ijbssnet.com/journals/Vol_3_No_7_April_2012/6.pdf.

[6] I. K. Made, "Studi Evaluasi Efektivitas Program Pegembangan Diri di SMA PGRI 2 Denpasar," Progr. Pascasarj. Univ. Pendidik. Indones., vol. 4, p. 10, 2014.

[7] S. Smaldino, Instructional Technology and Media for Learning (12th Edition), 12th ed. Pearson, 2018.

[8] T. Yulianti and S. Herpratiwi, "Pengembangan Bahan Ajar Mandiri Melalui Media Online Untuk Meningkatkan Kemampuan Public Speaking Mahasiswa Di Perguruan Tinggi Teknokrat Bandarlampung," 2014, [Online]. Available: http://jurnal.fkip.unila.ac.id/index.php/JT/article/view/5475/4226.

[9] Depdiknas, “Undang Undang Sistem Pendidikan Nasional,” p. 26, 2003, [Online]. Available: http://luk.staff.ugm.ac.id/atur/UU20-2003Sisdiknas.pdf.

[10] T. O.Nyumba, K. Wilson, C. J. Derrick, and N. Mukherjee, "The use of focus group discussion methodology: Insights from two decades of application in conservation," Methods Ecol. Evol., vol. 9, no. 1, pp. 20-32, 2018, doi: 10.1111/2041-210X.12860.

[11] R. A. Krueger, Focus Groups: A Practical Guide for Applied Research, 5th ed. United State of America: SAGE Publications, Inc, 2015.

[12] Koentjaraningrat, Metode Penelitian Masyarakat. Jakarta: PT. Gramedia, 2008.

[13] S. Arikunto, Dasar-Dasar Evaluasi Pendidikan, 2nd ed. Jakarta: Bumi Aksara, 2013. 